\title{
Pengaruh Heat Treatment untuk Mengembalikan Sifat Mekanik Kawat T-loop Segmental Stainless Steel terhadap Besaran Gaya yang Dihasilkan
}

\author{
Avi Laviana, Tono S. Hambali, Bergman Thahar, Endah Mardiati \\ Fakultas Kedokteran Gigi Universitas Padjadjaran Bandung
}

\begin{abstract}
Abstrak
Prosedur heat treatment dengan suhu dan teknik yang tepat pada pegas T-loop segmental stainless steel dapat mengembalikan sifak-sifat mekanik kawat yang menurun akibat prosedur pembengkokan kawat. Penelitian ini bertujuan membandingkan gaya yang dihasilkan oleh pegas T-loop segmental stainless steel tanpa dan dengan heat treatment pada suhu $450^{\circ} \mathrm{C}$ selama 15 menit, dengan berbagai jarak aktivasi dan gable. Desain penelitian adalah eksperimental laboratoris murni secara in vitro. Penelitian dilaksanakan di Laboratorium Kimia Murni FMIPA ITB pada tahun 2006. Sampel adalah 50 buah pegas T-loop segmental dengan gable: $0^{\circ}-0^{\circ}, 7,5^{\circ}-7,5^{\circ}$; $15^{\circ}-15^{\circ} ; 22,5^{\circ}-22,5^{\circ} ; 30-30^{\circ}$, terdiri atas 25 pegas tanpa heat treated dan 25 pegas dengan heat treated. Gaya diukur menggunakan autograph pada jarak tarik 1, 2, dan $3 \mathrm{~mm}$, serta hasilnya dilakukan analisis statistik ANOVA dengan desain faktorial 2 × 3 × 5 dan 5 replikasi tiap sel serta uji posthoc Student Newman Keuls dan Tukey. Hasil uji statistik menunjukkan bahwa perlakuan heat treated dibanding dengan tanpa heat treated serta interaksi antara perlakuan heat treatment dan gable memberikan efek yang signifikan terhadap gaya yang dihasilkan $(\mathrm{p}<0,05)$. Simpulan, heat treatment pada T-loop stainless steel menghasilkan efek berupa penurunan besar gaya yang dihasilkan. [MKB. 2015;47(3):167-73]
\end{abstract}

Kata kunci: Gaya, heat treatment, T-loop

\section{The Effect of Heat Treatment on Mechanical Properties in Restoring Stainless Steel Segmental T-Loop towards the Force Created}

\begin{abstract}
Heat-treatment procedure with precise temperature and technique on the stainless-steel segmental T-loop retraction spring can restore the mechanical properties that decreases after a wire-bending process. The goal of this study was to compare the force produced by a stainless-steel segmental T-loop spring without and with heat-treatment on $450^{\circ} \mathrm{C}$ for 15 minutes, with various activation distance and gable. The design of the study was in-vitro laboratory experimental design. This study was performed at the Chemistry Laboratory of the Faculty of Science, ITB in 2006. Sample included 50 segmental T-loop springs with $\alpha$ and $\beta$ angle of $0^{\circ}-0^{\circ}, 7.5^{\circ}-7.5^{\circ}$, $15^{\circ}-15^{\circ}$, and $22.5^{\circ}-22.5^{\circ}$, and $30^{\circ}-30^{\circ}$ which consisted of 25 springs without heat-treatment and 25 springs with heat-treatment. Force was measured using autograph with a retraction distance of 1 , 2, and $3 \mathrm{~mm}$ and the results were gained from ANOVA statistics analysis with a factorial design of $2 \times 3 \times 5$ and 5 replications for each cell and posthoc Student Newman Keuls and Tukey test. The result of the statistic test showed that heat-treatment compared to no heat-treatment and interaction between heat-treatment and gable gives significant effect to the force created ( $p$-value $<0.05$ ). In conclusion, the heat-treatment on the stainless steel T-loop produces an effect to decrease the created force. [MKB. 2015;47(3):167-73]
\end{abstract}

Key words: Force, heat-treatment, T-loop

Korespondensi: Avi Lavina drg., Fakultas Kedokteran Gigi Universitas Padjadjaran Bandung, Jalan Sekeloa Selatan, No. 1 Bandung, mobile 085974125421, e-mail avilaviana@yahoo.com 


\section{Pendahuluan}

Keberhasilan suatu perawatan ortodonti itu bergantung pada beberapa faktor, antara lain mekanika alat ortodonti yang adekuat. Faktorfaktor yang menentukan efektivitas mekanika alat ortodonti antara lain ketepatan pemilihan bahan, konfigurasi pegas, dan juga penanganan archwire. . $^{1-3}$

Stainless steel adalah bahan yang terus diteliti dan dikembangkan hingga saat ini dan telah digunakan secara luas dalam bidang ortodonti, antara lain sebagai archwire. Bahan stainless steel memiliki struktur dan sifat mekanik yang menguntungkan sebagai archwire antara lain dapat menghasilkan gaya yang cukup, rentang kerja yang luas, mudah dimanipulasi menjadi berbagai bentuk, dan sifat mekaniknya relatif stabil ketika dilakukan soldering dan welding. . $^{1,}$, 4,5

Tahap pembuatan archwire stainless steel melalui proses penggulungan, pemadatan, dan penarikan. Proses ini menghasilkan berbagai perubahan bentuk dan struktur kawat hingga akhirnya diperoleh archwire dengan sifatsifat mekanik yang menguntungkan, seperti kekuatan dan kekerasannya. Perubahan bentuk melalui pembengkokan kawat yang dilakukan di klinik pada saat pembuatan T-loop akan menimbulkan stress sehingga kawat akan mengalami penurunan sifat-sifat mekaniknya. ${ }^{6}$ Beberapa penelitian melaporkan mengenai teknik heat treated yang dapat mengembalikan sifat mekanik archwire stainless steel, antara lain menurunkan stress setelah dilakukan heat treated pada suhu $300-500^{\circ} \mathrm{C}$ selama 15 menit. Heat treated dapat pula menimbulkan efek samping yang merugikan jika teknik yang dilakukan tidak tepat, seperti penurunan sifatsifat mekanik yang berlebih, perubahan bentuk, dan penurunan daya tahan terhadap korosi akibat lepasnya ion-ion nickel dan chromium dari kawat. Ion-ion logam akan bercampur dengan saliva, bahkan mungkin diserap secara sistemik. Praktisi harus sangat memperhatikan teknik heat treated agar selama dan setelah perawatan ortodonti tidak berdampak toksik pada pasien. ${ }^{1,4}$

Salah satu teknik penutupan ruang pada perawatan ortodonti dengan pencabutan adalah memakai T-loop segmental. ${ }^{7-9}$ Teknik ini menjadi pilihan ketika operator tidak menghendaki friksi dan menginginkan kontrol gerakan tipping serta rotasi melalui pengaturan momen (Gambar 1). ${ }^{7}$ 10

Penelitian ini bertujuan mengetahui pengaruh heat treatment pada suhu $450^{\circ} \mathrm{C}$ selama 15 menit terhadap pegas segmental T-loop stainless steel, dengan berbagai variasi sudut gable dan jarak tarik terhadap besar gaya yang dihasilkan.

\section{Metode}

Bahan penelitian ini adalah 50 pegas T-loop stainless steel (Ormco) berpenampang 0,016 inci x 0,022 inci dengan tinggi $7 \mathrm{~mm}$, lebar 10
A

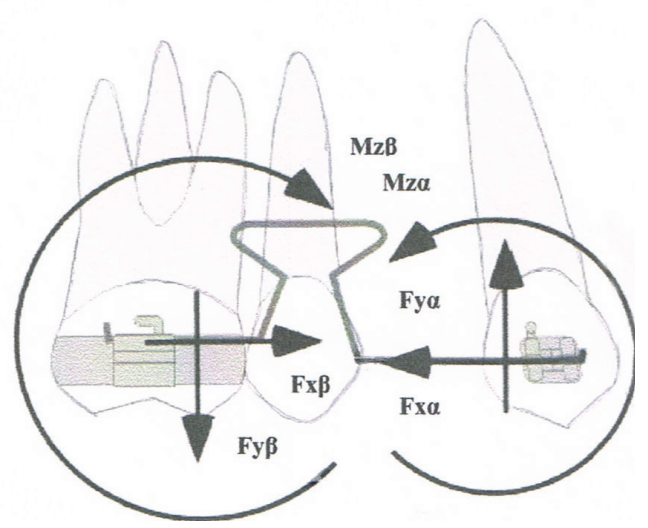

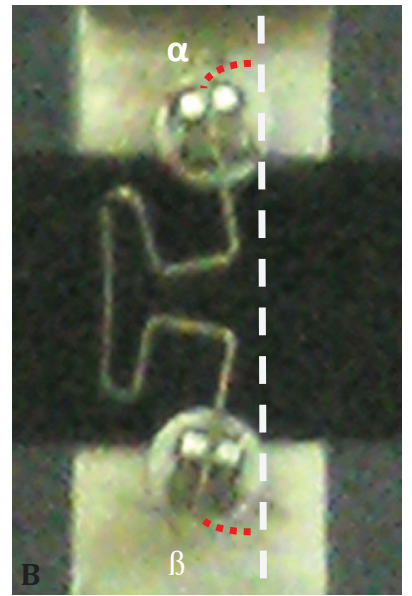

Gambar 1 Sistem Gaya yang Bekerja pada Pegas T-Loop Segmental

A. Gaya horizontal yang bekerja pada segmen anterior ( $F x \alpha$ ). Gaya vertikal yang bekerja pada segmen anterior (Fy $\alpha)$. Momen yang terjadi pada segmen anterior (Mz $\alpha$ ). Gaya horizontal yang bekerja pada segmen posterior (Fx $\beta$ ). Gaya vertikal yang bekerja pada segmen posterior (Fy $\beta$ ). Momen yang terjadi pada segmen posterior $(\mathrm{Mz} \beta)$. B. Alat uji terpasang pada autograph, memegang T-loop dengan variasi sudut ] gable $\alpha$ dan $\beta$. (Lab. Kimia Murni F. MIPA ITB). 
Tabel 1 Besar Gaya berdasarkan Faktor Perlakuan Heat Treated (A).

\begin{tabular}{ccccccc}
\hline \multirow{2}{*}{ Interaksi A } & \multicolumn{7}{c}{ Gaya (gF) } \\
\cline { 2 - 7 } & Rata-rata & Median & SB & Minimum & Maksimum & $\begin{array}{c}\text { Posthoc } \\
\text { Test* }^{*}\end{array}$ \\
\hline Tanpa HT & 308,83 & 285,00 & 156,84 & 68,00 & 652,00 & $\mathrm{a}$ \\
Dengan HT & 281,53 & 260,00 & 153,89 & 40,00 & 660,00 & $\mathrm{~b}$ \\
\hline
\end{tabular}

Keterangan: HT = heat treatment; *uji S-N-K dan Tukey

$\mathrm{mm}$, dan panjang $18 \mathrm{~mm}$, dengan kombinasi sudut anterior $(\alpha)$ dan posterior $(\beta)$ adalah $0^{\circ}-0^{\circ} ; 7,5^{\circ}-7,5^{\circ} ; 15^{\circ}-15^{\circ} ;$ dan $22,5^{\circ}-22,5^{\circ}$; $30-30^{\circ}$; masing-masing 5 buah. Seluruh pegas dikalibrasi menggunakan template dan diperiksa kesejajarannya menggunakan glass slab. Pada 25 pegas T-loop tidak dilakukan heat treated dan 25 pegas dilakukan heat treated dalam oven (Philip) pada suhu $450^{\circ} \mathrm{C}$ selama 15 menit.

Metode penelitian yang digunakan adalah penelitian eksperimental murni dan dilakukan di laboratorium secara in vitro. Desain alat uji untuk memegang pegas T-loop pada autograph dirancang oleh Laboratorium Kimia Murni Fakultas MIPA ITB dan dibuat oleh Laboratorium Fisika Teknik LIPI, Bandung. Alat tersebut terbuat dari bahan alumunium dan terdiri atas bagian yang statis, batang penarik yang dapat digerakkan, dudukan breket yang dapat berputar, dan breket standar edgewise ukuran slot 0,018 inci (Ormco). Pegas dipasang pada alat uji lalu diikat pada breket menggunakan ligature wire, kemudian alat uji dipasang pada
Universal Strength Tester Shimadzu Corporation Autograph. Autograph diatur pada angka 0 (nol), kemudian dilakukan penarikan sebesar $1 \mathrm{~mm}, 2$ $\mathrm{mm}$, dan $3 \mathrm{~mm}$, serta besar gaya yang dihasilkan dicatat dengan satuan $\mathrm{gF}$.

Penelitian dilakukan di Laboratorium Kimia Murni Fakultas MIPA Institut Teknologi Bandung. Uji statistik hasil penelitian menggunakan ANOVA, yaitu untuk menguji data dengan Desain Faktorial 2 × 3 × 5 dan 5 replikasi tiap sel. Untuk menguji hasil interaksi ketiga faktor bahan, gable, dan jarak tarik juga digunakan uji posthoc tes Student Newman Keuls dan Tukey pada taraf $5 \%$.

\section{Hasil}

Nilai gaya rata-rata yang dihasilkan oleh pegas retraksi T-loop segmental stainless steel tanpa dilakukan heat treated dibanding dengan heat treated, dengan besar sudut gable dan jarak aktivasi yang berbeda, yaitu pada stainless

Tabel 2 Besar Gaya berdasarkan Faktor Interaksi Perlakuan Heat Treated (A) dan Sudut Gable (B)

\begin{tabular}{ccccccc}
\hline \multirow{2}{*}{$\begin{array}{c}\text { Interaksi } \\
\text { AB }\end{array}$} & Rata-rata & Median & SB & Minimum & Maksimum & $\begin{array}{c}\text { Posthoc } \\
\text { Test }\end{array}$ \\
\cline { 2 - 7 } & 214,67 & 203,00 & 108,63 & 70,00 & 393,00 & $\mathrm{~b}$ \\
A1B1 & 244,07 & 258,00 & 131,52 & 68,00 & 485,00 & $\mathrm{~b}$ \\
A1B2 & 303,60 & 285,00 & 142,12 & 123,00 & 520,00 & $\mathrm{c}, \mathrm{d}$ \\
A1B3 & 378,53 & 362,00 & 154,87 & 175,00 & 620,00 & $\mathrm{e}$ \\
A1B4 & 403,27 & 400,00 & 167,20 & 168,00 & 652,00 & $\mathrm{e}$ \\
A1B5 & 167,00 & 170,00 & 87,93 & 40,00 & 300,00 & $\mathrm{a}$ \\
A2B1 & 234,00 & 225,00 & 115,28 & 90,00 & 410,00 & $\mathrm{~b}$ \\
A2B2 & 286,67 & 280,00 & 140,36 & 110,00 & 490,00 & $\mathrm{c}$ \\
A2B3 & 324,00 & 320,00 & 149,42 & 145,00 & 515,00 & $\mathrm{~d}$ \\
A2B4 & 396,00 & 390,00 & 172,21 & 155,00 & 660,00 & $\mathrm{e}$ \\
A2B5 & & &
\end{tabular}

Keterangan: A1=tanpa heat treatment; $\mathrm{A} 2=$ dengan heat treatment; $\mathrm{B}=$ berdasarkan interaksi dengan besar sudut gable

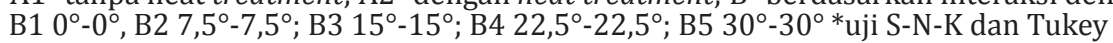


Avi Lavina: Pengaruh Heat Treatment untuk Mengembalikan Sifat Mekanik Kawat T-loop Segmental Stainless Steel

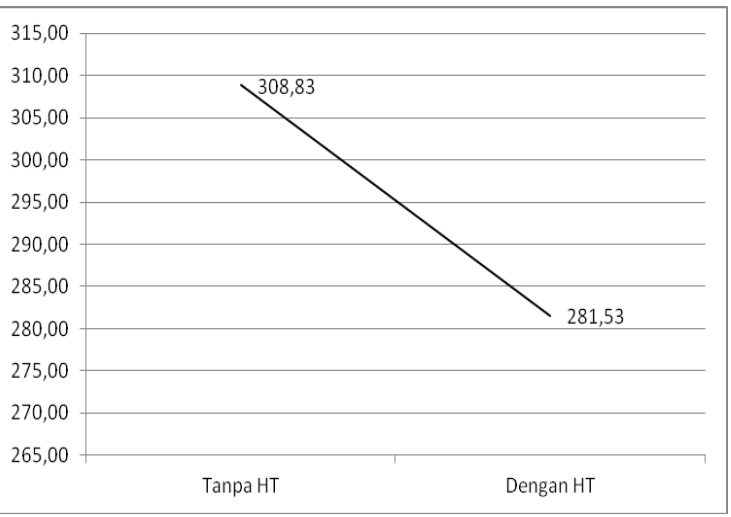

(A)

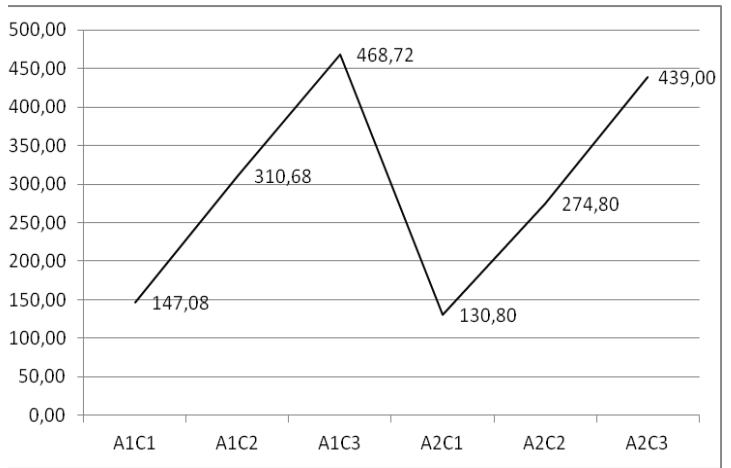

(C)

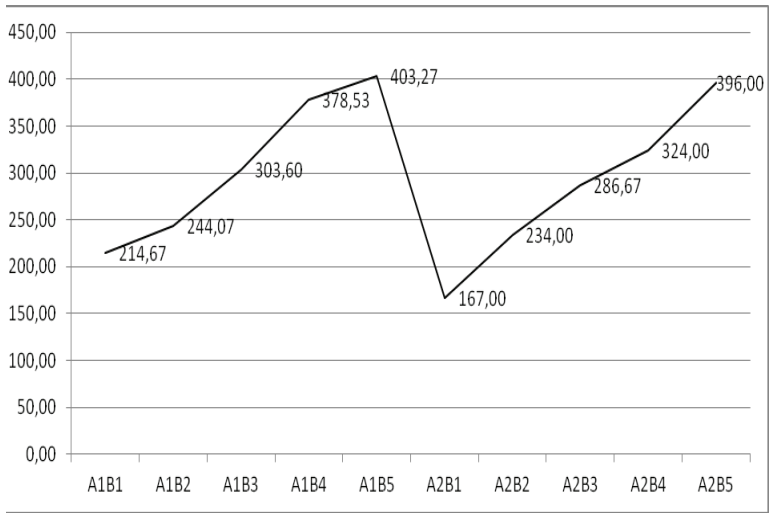

(B)

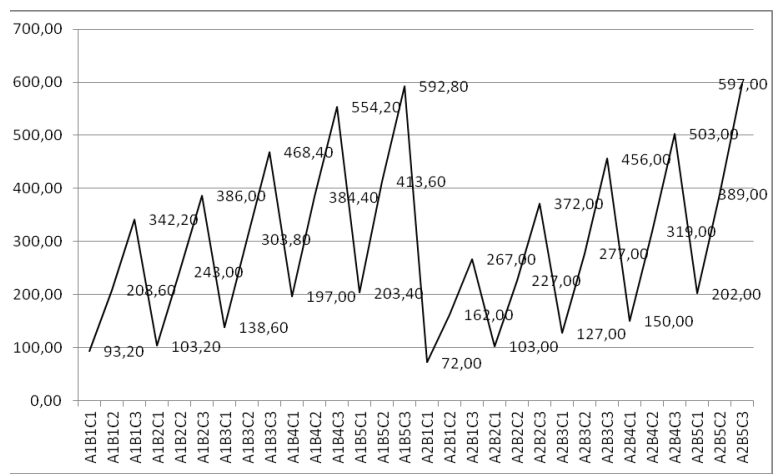

(D)

\section{Gambar 2 Besar Gaya berdasarkan Beberapa Faktor Perlakuan}

(A) Berdasarkan faktor perlakuan heat treated, gaya yang dihasilkan T-loop segmental stainless steel tanpa HT berbeda secara bermakna dengan yang diberi perlakuan HT.

Keterangan: HT = heat treatment. (B) berdasarkan interaksi perlakuan pada T-loop stainless steel dengan dan tanpa heat treatment dan gable, gaya yang dihasilkan T-loop tanpa heat treated (A1) dan dengan heat treatment (A2), menunjukkan kenaikan yang bermakna untuk setiap kenaikan sudut gable (B1-B5). (C) berdasarkan faktor interaksi perlakuan tanpa dan dengan heat treatment terhadap T-loop stainless steel, gaya yang dihasilkan (A1-A2) dan dengan dan jarak tarik 1, 2, 3 mm (C1-C3) menunjukkan perbedaan yang bermakna. (D) berdasarkan faktor interaksi bahan, gable, dan jarak tarik, gaya yang dihasilkan berdasarkan perlakuan pada T-loop stainless steel tanpa heat treatment (A1) dan dengan heat treatment (A2); sudut gable, (B1-B5) dan jarak tarik (C1-C3) menunjukkan perbedaan yang bermakna.

Tabel 3 Besar Gaya Berdasarkan Faktor Interaksi Perlakuan Heat Treated (A) dan Jarak Tarik (C)

\begin{tabular}{lcccccc}
\hline \multirow{2}{*}{$\begin{array}{c}\text { Interaksi } \\
\text { AC }\end{array}$} & Rata-rata & Median & SB & Minimum & Maksimum & Posthoc Test* $^{*}$ \\
\cline { 2 - 6 } A1C1 & 147,08 & 140,00 & 50,60 & 68,00 & 237,00 & $\mathrm{a}$ \\
A1C2 & 310,68 & 307,00 & 87,59 & 160,00 & 470,00 & $\mathrm{c}$ \\
A1C3 & 468,72 & 485,00 & 108,29 & 263,00 & 652,00 & $\mathrm{e}$ \\
A2C1 & 130,80 & 130,00 & 48,43 & 40,00 & 245,00 & $\mathrm{a}$ \\
A2C2 & 274,80 & 280,00 & 82,87 & 110,00 & 445,00 & $\mathrm{~b}$ \\
A2C3 & 439,00 & 460,00 & 119,44 & 195,00 & 660,00 & $\mathrm{~d}$ \\
\hline
\end{tabular}

Keterangan: $\mathrm{A} 1$ = tanpa heat treatment; $\mathrm{A} 2=$ dengan heat treatment; $\mathrm{C}=$ jarak aktivasi $\mathrm{C} 1=1, \mathrm{C} 2=2$, dan $\mathrm{C} 3=3 \mathrm{~mm}$; ${ }^{\mathrm{uji}}$ S-N-K dan Tukey 
Tabel 4 Besar Gaya berdasarkan Faktor Interakasi Heat Treated (A), Sudut Gable (B), dan Jarak Tarik (C)

\begin{tabular}{|c|c|c|c|c|c|c|}
\hline \multirow{2}{*}{$\begin{array}{c}\text { Interaksi } \\
\text { ABC }\end{array}$} & \multicolumn{6}{|c|}{ Gaya (gF) } \\
\hline & Rata-rata & Median & SB & Minimum & Maksimum & Posthoc Test* \\
\hline A1B1C1 & 93,20 & 93,00 & 18,75 & 70,00 & 115,00 & $a, b$ \\
\hline A1B1C2 & 208,60 & 203,00 & 27,37 & 175,00 & 238,00 & $\mathrm{~d}, \mathrm{e}$ \\
\hline A1B1C3 & 342,20 & 338,00 & 37,12 & 292,00 & 393,00 & h,i \\
\hline A1B2C1 & 103,20 & 113,00 & 27,81 & 68,00 & 132,00 & $a, b, c$ \\
\hline $\mathrm{A} 1 \mathrm{~B} 2 \mathrm{C} 2$ & 243,00 & 258,00 & 55,83 & 160,00 & 307,00 & e,f \\
\hline A1B2C3 & 386,00 & 410,00 & 81,64 & 263,00 & 485,00 & $i, j$ \\
\hline A1B3C1 & 138,60 & 140,00 & 11,80 & 123,00 & 155,00 & $\mathrm{~b}, \mathrm{c}$ \\
\hline A1B3C2 & 303,80 & 285,00 & 29,41 & 280,00 & 345,00 & $\mathrm{~g}, \mathrm{~h}$ \\
\hline A1B3C3 & 468,40 & 465,00 & 41,40 & 428,00 & 520,00 & $i, j$ \\
\hline $\mathrm{A} 1 \mathrm{~B} 4 \mathrm{C} 1$ & 197,00 & 205,00 & 14,40 & 175,00 & 210,00 & e \\
\hline A1B4C2 & 384,40 & 362,00 & 37,51 & 350,00 & 430,00 & $i, j$ \\
\hline A1B4C3 & 554,20 & 542,00 & 50,27 & 505,00 & 620,00 & $\mathrm{~m}$ \\
\hline A1B5C1 & 203,40 & 205,00 & 26,22 & 168,00 & 237,00 & $\mathrm{~d}, \mathrm{e}$ \\
\hline $\mathrm{A} 1 \mathrm{~B} 5 \mathrm{C} 2$ & 413,60 & 400,00 & 32,47 & 393,00 & 470,00 & $\mathrm{j}, \mathrm{k}$ \\
\hline A1B5C3 & 592,80 & 582,00 & 33,6 & 570,00 & 652,00 & $\mathrm{~m}$ \\
\hline $\mathrm{A} 2 \mathrm{~B} 1 \mathrm{C} 1$ & 72,00 & 70,00 & 20,80 & 40,00 & 95,00 & $\mathrm{a}$ \\
\hline $\mathrm{A} 2 \mathrm{~B} 1 \mathrm{C} 2$ & 162,00 & 170,00 & 30,94 & 110,00 & 185,00 & $c, d$ \\
\hline A2B1C3 & 267,00 & 285,00 & 43,10 & 195,00 & 300,00 & $f, g$ \\
\hline A2B2C1 & 103,00 & 105,00 & 10,37 & 90,00 & 115,00 & $a, b, c$ \\
\hline A2B2C2 & 227,00 & 225,00 & 20,80 & 205,00 & 255,00 & $e, f$ \\
\hline A2B2C 3 & 372,00 & 365,00 & 25,64 & 340,00 & 410,00 & $i, j$ \\
\hline A2B3C1 & 127,00 & 130,00 & 10,95 & 110,00 & 140,00 & $a, b, c$ \\
\hline A2B3C2 & 277,00 & 280,00 & 18,57 & 250,00 & 300,00 & $f, g$ \\
\hline A2B3C 3 & 456,00 & 460,00 & 25,84 & 420,00 & 490,00 & $\mathrm{k}, \mathrm{l}$ \\
\hline A2B4C1 & 150,00 & 150,00 & 3,53 & 145,00 & 155,00 & $b, c, d$ \\
\hline A2B4C2 & 319,00 & 320,00 & 8,21 & 305,00 & 325,00 & $\mathrm{~g}, \mathrm{~h}$ \\
\hline A2B4C3 & 503,00 & 505,00 & 11,51 & 485,00 & 515,00 & 1 \\
\hline A2B5C1 & 202,00 & 195,00 & 35,99 & 155,00 & 245,00 & $\mathrm{~d}, \mathrm{e}$ \\
\hline A2B5C 2 & 389,00 & 390,00 & 43,50 & 325,00 & 445,00 & $i, j$ \\
\hline A2B5C3 & 597,00 & 615,00 & 54,84 & 515,00 & 660,00 & $\mathrm{~m}$ \\
\hline
\end{tabular}

steel tanpa heat treated gaya terkecil $93,20 \mathrm{gF}$ dihasilkan oleh T-loop dengan gable $0^{0}-0^{0}$ dan aktivasi sejauh $1 \mathrm{~mm}$. Gaya terbesar 592,80 gF dihasilkan oleh T-loop dengan gable $30^{\circ}-30^{0}$ dengan jarak aktivasi $3 \mathrm{~mm}$. Pada T-loop stainless steel dengan heat treated, diketahui bahwa gaya terkecil dihasilkan oleh pegas retraksi T-loop heat treated dengan gable $0^{0}-0^{0}$ dan pada jarak aktivasi $1 \mathrm{~mm}$, yaitu sebesar 72,0 gF, dan gaya terbesar yaitu $597 \mathrm{gF}$ dihasilkan pada gable $30^{\circ}$ $30^{\circ}$ dengan jarak aktivasi $3 \mathrm{~mm}$. Gaya optimum untuk retraksi gigi kaninus dicapai dengan gable $0^{0}-0^{0}$ dan 7,50 $-7,5^{0}$ dengan jarak aktivasi $1 \mathrm{~mm}$.

Gaya yang dihasilkan oleh T-loop stainless steel tanpa heat treated secara keseluruhan lebih besar jika dibanding dengan gaya yang dihasilkan oleh T-loop dengan heat treated. Pada T-loop dengan besar sudut gable dan jarak aktivasi yang 
sama, gaya yang dihasilkan oleh pegas stainless steel tanpa heat treated selalu lebih besar dibanding dengan gaya yang dihasilkan oleh pegas dengan heat treated, kecuali pada gable $30^{\circ}-30^{\circ}$ dengan jarak aktivasi $3 \mathrm{~mm}$ pada T-loop dengan heat treated menunjukkan gaya sedikit lebih besar. Perhitungan ukuran sampel untuk rancangan percobaan tiga faktor (perlakuan heat treatment, jarak tarik, dan sudut gable) dengan masing-masing tingkat 2,3 , dan 5 sehingga akan terbentuk $2 \times 3 \times 5$ perlakuan, untuk menghitung sampel minimum digunakan rumus sampel dari Federer.

Rumus sampel

$(n-1)(k-1) \geq 15$

atau

$n \geq 1+\frac{15}{(k-1)}$

Dengan

$\mathrm{N}=$ ukuran sampel minimal yang dibutuhkan

$\mathrm{K}=$ banyaknya perlakuan dalam rancangan

percobaan yang dilakukan

Banyaknya unit percobaan adalah

$n \times k$

Dalam rancangan percobaan ini desainnya adalah terdapat 2 bahan T-loop stainless steel, yaitu tanpa heat treatment dan dengan heat treatment, 3 jarak tarik, dan 5 besar sudut gable, atau akan didapat 30 perlakuan yang berbeda. Ukuran sampel minimal yang diperlukan adalah:

$n \geq 1+\frac{15}{(30-1)}$

$n \geq 1,517 \approx 2$

Berdasarkan atas penghitungan, minimal banyak unit percobaan atau replikasi minimal untuk setiap perlakuan adalah 2 atau total sampel minimal adalah $2 \times 30=60$ unit percobaan yang dipersyaratkan. Karena dalam penelitian ini dilakukan 5 replikasi untuk setiap perlakuan maka didapatkan 5x30=150 unit percobaan. Dengan demikian, syarat minimal sampel sudah terpenuhi.

Berdasarkan penghitungan dengan ANOVA dari SPSS versi 19 dengan rancangan percobaan 2x3x5 dengan 5 replikasi, diketahui bahwa pada jenis perlakuan T-loop stainless steel tanpa dan dengan heat treatment dan interaksi di antara bahan dengan sudut gable $0^{\circ}-0^{\circ} ; 7,5^{\circ}-7,5^{\circ}$; $15^{\circ}-15^{\circ}$; dan $22,5^{\circ}-22,5^{\circ} ; 30-30^{\circ}$ dan jarak tarik (1, 2, $3 \mathrm{~mm}$ ) memberikan efek yang signifikan terhadap gaya yang dihasilkan (nilai $\mathrm{p}<0,05$ ) kecuali interaksi antarperlakuan heat treatedjarak tarik, dan interaksi heat treated-sudutjarak tarik, karena nilai p (sig) >0,05.

Berdasarkan atas faktor T-loop stainless steel dengan dan tanpa heat treatment maka dapat dilihat bahwa gaya yang dihasilkan oleh stainless steel tanpa heat treatment lebih besar dibanding dengan heat treatment (Gambar 2A). Gaya yang dihasilkan tersebut berbeda bermakna pada taraf 5\% dengan menggunakan Uji posthoc Student Newman Keuls dan Tukey (perlakuan yang diikuti oleh huruf yang berbeda menunjukkan perbedaan rata-rata yang bermakna) (Tabel 1). Gambar 2A memperlihatkan grafik gaya berdasarkan faktor A, yaitu T-loop stainless steel tanpa dan dengan heat treatment.

Berdasarkan faktor interaksi T-loop stainless steel tanpa heat treatment (A1) dan dengan heat treatment (A2) dan variasi besar sudut gable (B1-B5) dapat dilihat bahwa gaya yang dihasilkan akan semakin besar seiring dengan membesarnya sudut gable untuk perlakuan yang sama (Gambar 2B). Gaya yang dihasilkan tersebut berbeda secara bermakna pada taraf 5\% dengan menggunakan Uji posthoc Student Newman Keuls dan Tukey (perlakuan yang diikuti oleh huruf yang berbeda menunjukkan perbedaan rerata yang bermakna) (Tabel 2).

Berdasarkan faktor interaksi perlakuan heat treatment terhadap T-loop stainless steel (A1A2) dan jarak tarikan (C1-C3) dapat dilihat bahwa gaya yang dihasilkan akan semakin besar seiring dengan membesarnya jarak tarik untuk perlakuan yang sama (Gambar 2C). Gaya yang dihasilkan tersebut berbeda secara bermakna pada taraf 5\% dengan mempergunakan Uji posthoc Student Newman Keuls dan Tukey (perlakuan yang diikuti oleh huruf yang berbeda menunjukkan perbedaan rata-rata yang ternyata bermakna) (Tabel 3).

Berdasarkan faktor interaksi perlakuan heat treatment T-loop stainless steel (A1-A2), sudut gabel (B1-B5), dan jarak tarik (C1-C3) dapat dilihat bahwa gaya yang dihasilkan akan semakin besar seiring dengan membesarnya jarak tarik untuk sudut yang sama dan bahan yang sama, begitu juga dengan bertambahnya sudut atau bertambahnya jarak tarik atau berbedanya perlakuan (Gambar 2D). Gaya yang dihasilkan tersebut berbeda secara bermakna pada taraf 
5\% dengan menggunakan Uji posthoc Student Newman Keuls dan Tukey (perlakuan yang diikuti oleh huruf yang berbeda menunjukkan perbedaan rata-rata yang bermakna) (Tabel 4).

\section{Pembahasan}

Penelitian ini dilakukan di laboratorium secara in vitro untuk mengukur besar gaya yang dihasilkan oleh pegas retraksi T-loop segmental stainless steel berdiameter 0,016 inci x 0,022 inci dan diberi gable dengan besar sudut anterior $(\alpha)$ dan posterior $(\beta): 0^{0}-0^{0} ; 7,5^{0}-7,5^{0} ; 15^{0}-15^{0}$; $22,5^{0}-22,5^{0} ; 30^{0}-30^{0}$, tanpa perlakuan heat treated dan dengan perlakuan heat treated, pada jarak tarik 1, 2, dan $3 \mathrm{~mm}$, yang mewakili jarak aktivasi yang umum dilakukan di klinik.

Berdasarkan penelitian, gaya yang diperoleh pegas T-loop stainless steel tanpa heat treated berkisar antara 93,20 gF hingga 592,80 gF; dan 72,00 gF hingga 597,00 gF untuk pegas T-loop stainlesssteeldengan heattreated.Hasilpenelitian ini sesuai dengan pernyataan mengenai sifat mekanik archwire stainless steel yang mengalami perubahan sifat-sifat mekaniknya yaitu ketika dilakukan heat treated kecuali pada penarikan T-loop dengan gable $30^{\circ}-30^{\circ}$ dengan jarak tarik $3 \mathrm{~mm}$ menghasilkan gaya lebih tinggi dibanding dengan tanpa heat treated. Kemungkinan pada pembengkokan kawat dengan sudut yang besar akan mengakibatkan kerusakan struktur kawat yang tidak dapat diperbaiki dengan prosedur heat treated, bahkan prosedur heat treated semakin menurunkan kekuatan bahan.

Gaya optimum untuk retraksi kaninus dihasilkan pegas T-loop segmental stainless steel dengan gable $0^{0}-0^{0}$ dan $7,5^{0}-7,5^{0}$ dengan jarak aktivasi $1 \mathrm{~mm}$. Walaupun pada penelitian ini terdapat gaya optimum yang memenuhi syarat untuk retraksi kaninus sesuai dengan Proffit, yaitu 70-120 gF per gigi untuk menghasilkan gerakan translasi, namun seluruh data penelitian ini merupakan data laboratoris yang pada penerapannya harus mempertimbangkan sistem gaya lain yang bekerja pada alat tersebut. ${ }^{5}$

Simpulan, bahwa perlakuan tanpa dan dengan heat treatment pada pegas T-loop stainless steel dan interaksi bahan dengan sudut gable dan jarak tarik memberikan efek berupa penurunan besar gaya yang dihasilkan.

\section{Daftar Pustaka}

1. Cuoghi OA, Kasbergen GF, Santos PH, Mendonca MR, Tandeli PM. Effects of heat treatment on stainless steel orthodontic wires. Braz Oral Res. 2011;25(2):128-34.

2. Sankar SG, Shetty S, Karanth D. A comparative study of physical and mechanical properties of the different grades of Australian stainless steel wires. Trends Biomater Artif Organs. 2010;25(2):67-74.

3. Blaya MBG, Westphalen GH, Guimaraes MB, Hirakata LM. Evaluation of tensile strength of different configuration of orthodontic retraction loops for obtaining optimized forces. Stomatologija. 2009;11(2):66-9.

4. Brantley WA, Alapati SB. Heat treatment of dental alloys: a review. Metallurgy-advances in materials and processes [Internet]. 2012 (diunduh 12 Mei 2014). Tersedia dari: http://dx.doi.org/10.577772/52398.

5. Proffit WR, Fields HW Jr, Sarver DM, Ackerman JL. Contemporary orthodontics. Edisi ke-5. St Louis, Missouri: Mosby; 2013.

6. Acharya KA, Jayade VP. Metallurgical properties of stainless steel orthodontic archwires: a comparative study. Trends Biomater Artif Organs. 2005;18(2):125-36.

7. Gajda S, Chen J. Comparison of threedimensional orthodontic load systems of different commercial archwire for space closure. Angle Orthod. 2012;82(2):333-9.

8. Felemban NH, Al Sulaiman FF, Murshid ZA, Hassan AH. En masse retraction versus two step retraction of anterior teeth in extraction treatment of bimaxillary protrusion. J Orthod Sci. 2013;2(1):28-37.

9. Katona TR, Isikbay SC, Chen J. Effects of first- and second-order gable bends on the orthodontic load systems produced by T-loop archwires. Angle Orthod J. 2014;84(2):3507.

10. Bisol GK, Rocha R. Laboratorial study of the cuspid's retraction timing and tipping effects during space closure, using the segmented arch technique. Dental Press J Orthod. 2010;15(1):53-64. 